Гуртина Л. Г., головний інженер (BAT "УНIПРОМ", м. Київ), ORCID: 0000-0003-4521-1541, Харин П. Л., завідувач проектною групою (BАT "УНIПРОМ, м. Київ), ORCID: 0000-0001-7858-0912, Хлапук М. М., Д.т.н., проф., директор навчально-наукового інституту водного господарства та природооблаштування (Національний університет водного господарства та природокористування, м. Рівне), ORCID: 0000-0001-5469-418, Шумінський В. Д., К.т.н., провідний науковий співробітник (ДП «Державний науково-дослідний інститут будівельних конструкцій», м. Київ), ORCID: 0000-0001-9270-6649

\title{
ЕФЕКТИВНІСТЬ РОБОТИ СПОРУД 3 ҐРУНТОВИХ МАТЕРІАЛІВ, ПІДСИЛЕНИХ ГЕОРЕШІТКАМИ, З ВРАХУВАННЯМ СЕЙСМІЧНИХ вПЛИВІВ
}

В статті розглянуто застосування синтетичних матеріалів, які представлені геотекстилем, геосітками, геомембранами, геокомпозитами та георешітками, що використовуються в різних сферах будівництва. Особливу увагу приділено георешіткам, особливостям їх роботи та використання як армуючих елементів в спорудах з ґрунтових матеріалів різноманітного призначення, в різних галузях народного господарства. Обґрунтовано ефективність та надійність їх роботи, включаючи роботу в сейсмічних регіонах. Головна мета застосування георешіток - підвищення міцності і надійності конструкції, їі експлуатаційних показників, особливо в умовах сейсмічних впливів. Представлені розрахунки армованих споруд з ґрунту, які виконуються в два етапи: етап 1 включає розрахунок загальної (зовнішньої) стійкості споруди, при якому визначаються габаритні розміри споруди 3 армованого ґрунту та довжина георешіток. Етап 2 стосується розрахунку на місцеву (внутрішню) стійкість (метод «подвійного клину»), при якому перевіряється міцність та вертикальний крок георешіток, міцність з'єднання георешіток з облицюванням. При влаштуванні споруд в сейсмічних районах в розрахунках стійкості враховуються сейсмічні дії. Зроблений аналіз роботи георешіток в різних спорудах, особливо при підсиленні ними споруд 3 ґрунтових матеріалів, а також при багаточисельних натурних випробуваннях в різних умовах при сейсмічних впливах. Визначені основні сфери застосування геосинтетиків. Представлені результати натурних випробувань споруд з ґрунтових матеріалів, підсилених георешітками, в умовах сейсмічних впливів та позитивний дос28 
від їх експлуатації в багатьох сейсмічних регіонах різних країн, які можуть бути використанні при прийнятті технічних рішень з підвищення ефективності роботи таких споруд і з вибору конструктивних рішень їх захисту від сейсмічних впливів.

Ключові слова: георешітки одновісні, двовісні та тривісні, армування георешітками споруд з ґрунтових матеріалів, підпірні стінки, сейсмічні впливи, натурні випробування.

Вступ. У дорожньому, цивільному та гідротехнічному будівництві, при влаштуванні захисних та утримуючих споруд, при захисті берегів водних об'єктів, підсилення споруд з ґрунтових матеріалів, при сейсмічних впливах широко застосовуються георешітки Tensar.

Мета роботи - привернути увагу спеціалістів до ефективності роботи георешіток в різних спорудах, особливо при підсиленні ними споруд з ґрунтових матеріалів, які позитивно зарекомендували себе в період експлуатації і, особливо, при сейсмічних впливах.

Методика досліджень. Аналіз роботи георешіток в різних спорудах, особливо при підсиленні ними споруд з ґрунтових матеріалів, а також при багаточисельних натурних випробуваннях в різних умовах при сейсмічних впливах.

Загальна частина. Сучасні геосинтетичні матеріали мають великі можливості для вирішення багатьох проблем у галузях транспорту, будівництва, гідротехніки при будівництві, реконструкції та в період експлуатації об'єктів. Основні сфери застосування геосинтетиків: в дорожньому будівництві, дренажних конструкціях, для армування споруд з ґрунтових матеріалів, захисних спорудах, для гідроізоляції конструкцій та споруд, протиерозійного захисту. У світі випускається близько 380-400 різних видів геосинтетичних матеріалів. Широке застосування геосинтетиків у будівництві обумовлено їх високими фізико-механічними властивостями: міцністю, стійкістю до впливу кліматичних і гідрогеологічних факторів, довговічністю (40120 років) i, головним чином, екологічною безпекою.

Одними із перших в світі жорсткі георешітки почала виготовляти компанія Tensar International у Великобританії та США за спеціальною технологією. Георешітки Tensar $€$ одним з довговічних армуючих синтетичних елементів, що застосовуються у будівництві. Мета їх застосування - підвищення міцності і надійності конструкції, її експлуатаційних показників, особливо в умовах сейсмічних впливів. При зведенні споруд різного призначення застосовуються, в основному, одновісні та тривісні георешітки Tensar. 
Одновісні георешітки Tensar широко використовуються для зведення армоґрунтових підпірних стін та при підсиленні споруд 3 ґрунтових матеріалів. Технологія влаштування таких споруд не потребує додаткових механізмів та спеціальних навичок. Завдяки пошаровому ущільненню ґрунту засипки або тіла ґрунтової споруди забезпечується утворення масиву ґрунту, який завдяки спільній роботі з георешіткою прискорює процес консолідації ґрунту.

Одновісні георешітки Tensar використовуються при влаштуванні тюфяків (матраців) для укріплення берегів водних об'єктів. Тривісні георешітки Tensar мають шестикутну форму отворів, що забезпечує рівномірний розподіл зусиль в оточуючому грунті. Впродовж багатьох років підсилення слабких ґрунтів вирішувалося завдяки двовісним георешіткам, але на початку 2000-х років з'явилися тривісні георешітки Tensar TriAx ${ }^{\mathrm{TM}}$. Їх робота набагато перевершує за своїми експлуатаційними характеристиками двовісні георешітки та дозволяє вирішувати наступні задачі: збільшення несучої здатності слабких ґрунтів; витримування високих транспортних навантажень на дороги при зменшенні товщини конструктивних шарів; виключення нерівномірних осідань тощо. При ущільненні ґрунту засипки його частинки проникають крізь отвори георешітки та взаємодіють з нею (розклинюються і передають зусилля на всі сторони рівномірно) та між собою і утворюють армований, напружений шар ґрунту (з решітки і ґрунту) з покращеними характеристиками міцності. Розклинювання ґрунту засипки в отворах георешітки дозволяє їй чинити опір горизонтального зсуву насипу і тим самим збільшити несучу здатність слабкого шару ґрунту. Структурні властивості армованого шару грунту залежать від величини навантаження і гранулометричного складу грунту засипки. Завдяки правильному підбору співвідношення різних фракцій грунту засипки ефект розклинювання підсилюється, запобігаючи тим самим горизонтальному руху частинок, що забезпечує надійність роботи конструкції. При динамічному (сейсмічному) впливі армований, напружений шар ґрунту не перешкоджає вертикальному переміщенню дрібних частинок грунту, що підвищує зсувостійкість споруди. Опір армогрунтових споруд при землетрусі $€$ результатом взаємодії георешітки та ґрунту, що призводить до створення дуже пружнього композитного матеріалу, який поглинає енергію землетрусу, залишаючись неушкодженим. Георешітки Tensar в основах дорожніх покриттів забезпечують додаткову жорсткість і пружність для ущільненого гранульованого шару ґрунту при зменшенні товщини конструктивних шарів, забезпечуючи збереження ці- 
лісності доріг під час сейсмічних впливів.

За останні кілька десятиліть землетруси в усьому світі стали серйозною проблемою і всі розробки і випробування, пов'язані з сейсмостійким проектуванням і відновленням споруд, набули великої значущості. Протягом багатьох років ґрунтові споруди, посилені георешітками Tensar, були побудовані в районах, схильних до землетрусів. Поєднання ґрунта з георешітками Tensar призводить до створення пружнього композитного матеріалу з високою пластичністю для створення конструкції будь-якої форми, стійкою до землетрусів і здатної безпечно поглинати енергію землетрусу без видимих пошкоджень.

Ефективність ґрунтових споруд (підпірних стін, дамб), посилених георешітками, була доведена при декількох трагічних землетруcax в Японії (Kobe, 1995, Chi-Chi, 1999), при яких армовані споруди з ґрунту витримали сейсмічні удари, залишалися працездатними та мали лише незначні дрібні поверхневі ушкодження. В той же час традиційні гравітаційні та кутникові залізобетонні стінки були фактично зруйновані (рис. 1). Під час землетрусу в Новій Зеландії (Крайстчерч, (пікові прискорення землетрусу $0,52 \mathrm{~g}$ по вертикалі і $0,71 \mathrm{~g}$ по горизонталі) споруди на Фіцджеральд-авеню зазнали значних руйнувань (рис. 2). Однак споруди прибережної ділянки Carlton Mill Road, побудовані в 1991 році з використанням георешіток Tensar, не зазнали жодних видимих ознак землетрусу. Землетруси в Новій Зеландії (Крайстчерч, 09/2010, 02/2011 і 06/2011) показали, що ґрунтові споруди, армовані георешітками, можуть ефективно використовуватися як основне рішення для запобігання розрідження ґрунту і пов'язаного з ним пошкодження будинків шляхом просідання. Це сприяло більш широкому застосуванню георешіток при проектуванні підпірних споруд, дамб, кріплень укосів та доріг.

Більшість методів розрахунку армованих споруд з ґрунту засновані на граничній рівновазі. В разі сейсмічного впливу додаткові інерційні навантаження, викликані землетрусом, включаються в еквівалентні статичні навантаження і розраховуються як квазістатичні методи розрахунку. Розрахунки армованих споруд з ґрунту виконуються в два етапи. Етап 1 включає розрахунок загальної (зовнішньої) стійкості споруди, при якому визначаються габаритні розміри споруди з армованого ґрунту та довжини георешіток з армованого ґрунту з врахуванням класу наслідків (відповідальності) споруди (рис. 3). Це, по суті, розрахунок гравітаційної утримуючої стінки на зсув (рис. 3, а), на перекидання (рис. 3, б), на втрату несучої здатності (рис. 3, в). Ро- 
зрахунки загальної стійкості споруд (рис. 3, г) виконуються за методом круглоциліндричних поверхонь ковзання або за методом Г. М. Шахунянца [1; 2]. При використанні геосинтетичних матеріалів розрахунок загальної стійкості споруд слід уточнювати згідно з [3].

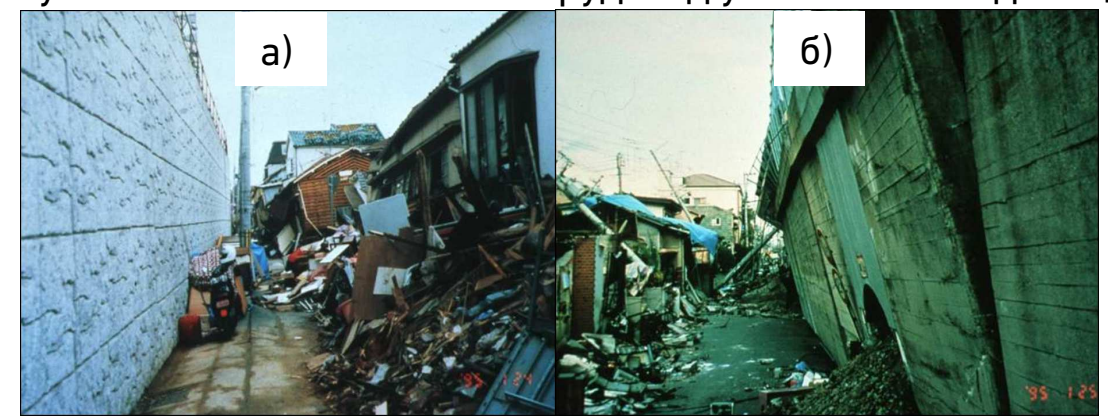

Рис. 1. Стан підпірних стінок після землетрусу в 1995 році в Кобе (Японія):

а) армованої стінки з ґрунту; б) гравітаційної залізобетонної стінки

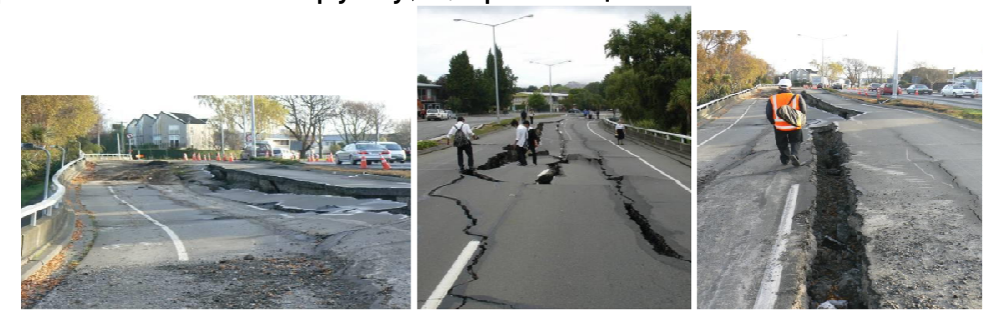

Рис. 2. Стан автодороги після землетрусу в Крайстчерчі (Нова Зеландія) в 2011 році

Етап 2 стосується розрахунку на місцеву (внутрішню) стійкість (метод «подвійного клину»), при якому перевіряється міцність та вертикальний крок георешіток, міцність з'єднання георешіток з облицюванням. При влаштуванні споруд в сейсмічних районах в розрахунках стійкості враховуються сейсмічні дії. При розрахунку за етапом 2 розрахункова схема умовно поділяється на два клини (рис. 4, а): клин 1 (Wedge 1) та клин 2 (Wedge 2). Мета розрахунку за етапом 2: переконатися, що опір (сили тертя $\mathrm{T}_{1}+\mathrm{T}_{2}+\mathrm{T}_{3}$ ), що утворюється облицюванням і армуванням ґрунту, яке перетинається клином 2, є достатнім, щоб уникнути втрати місцевої (внутрішньої) стійкості споруди. Горизонтальну силу, необхідну для рівноваги двох клинів $Z_{i}$, визначають з рівняння рівноваги сил, прикладених до клину 2 (рис. 4, б).

$$
Z_{i}=\sum H_{i}-\sum V_{i} \cdot \tan \left(\varphi^{\prime}-\theta_{i}\right),
$$

де $\sum H_{i}$ - сума всіх горизонтальних сил, рівна $E_{a h ;} \sum V_{i}$ - сума всіх 
вертикальних сил рівна, $W_{i}+Q_{2}+E_{a v} ; \varphi^{\prime}-$ кут внутрішнього тертя грунту засипки, град.; $\theta_{i}$ - змінний кут нахилу клинів 1 та 2 до горизонту, град.

a)

б)
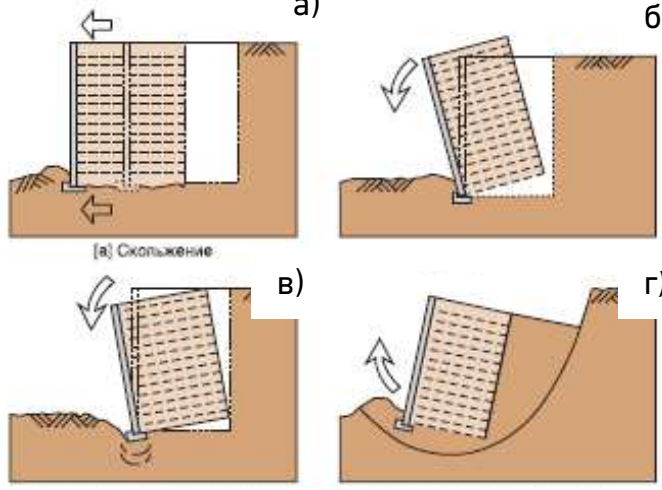

в)

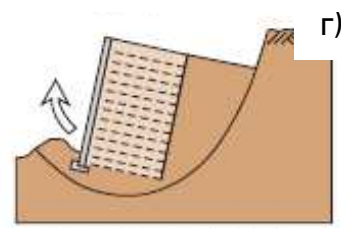

Рис. 3. Схеми до розрахунку споруд з армованого грунту за етапом 1:

а) на зсув; б) на перекидання; в) на втрату несучої здатності; г) на втрату загальної стійкості
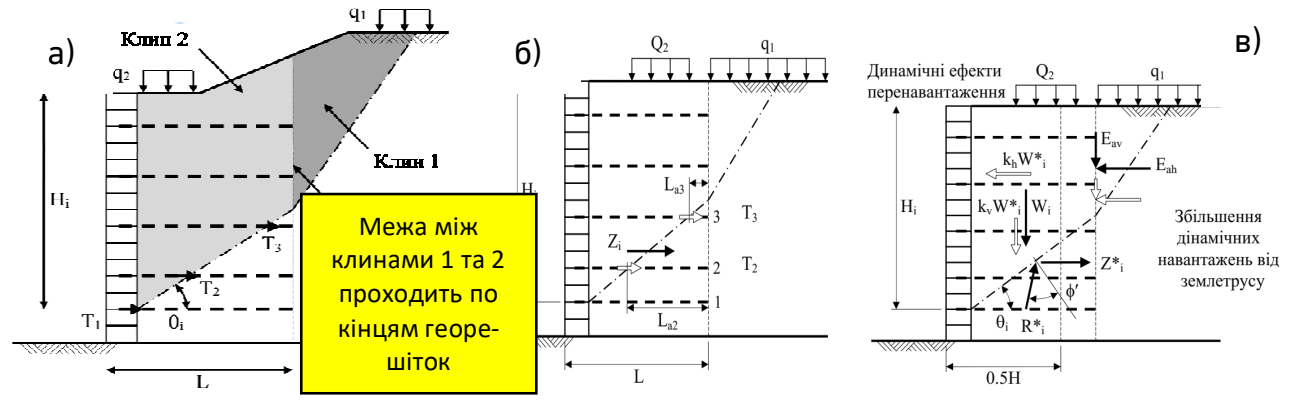

Рис. 4. Схеми до розрахунку внутрішньої стійкості за етапом 2:

а) поділ схеми на два клини; б) сили, що діють на споруду; в) врахування сейсмічних впливів

Для випадку сейсмічного впливу процедура розрахунку аналогічна, як і для статичних дій (рис. 4, б), але з додатковою дією сейсмічних сил (рис. 4, в). Основна відмінність полягає у врахуванні додаткових сейсмічних сил, що діють на клин 2 (рис. 4, в).

Для визначення кута $\theta_{i}$ в клині 2 проводять кути через $3^{\circ}$ і визначають при якому куті буде максимальна сила опору в клині 2 (рис. 5, а). Кут $\theta_{i}$ в клині 1 проводять в місцях перетину, де армування перетинає облицювання і змінюється до тих пір, поки не буде отримана максимальна сила опору (рис. 5, б). Для пошуку критичного 
клину з двох частин (клини 1 та 2), розглядається велика кількість комбінацій клинів з викоритстанням програмного забезпечення.
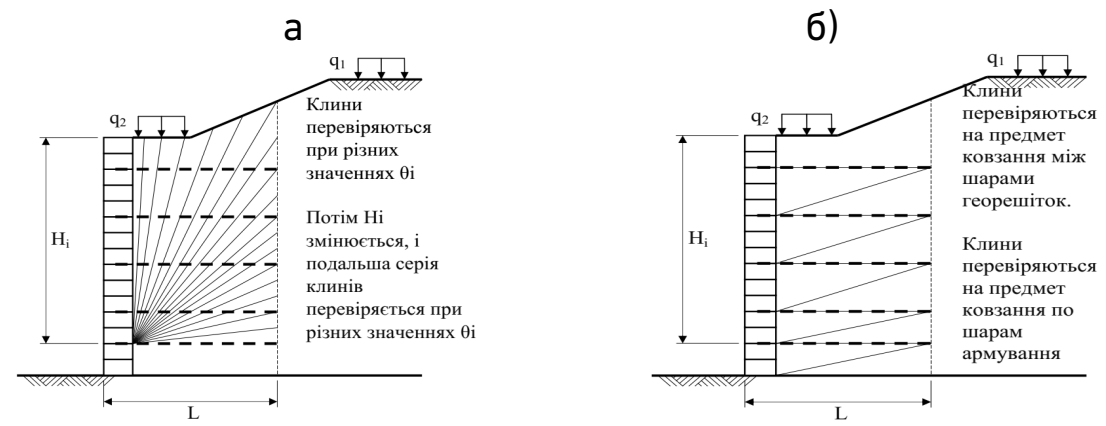

Рис. 5. Пошук оптимального кута $\vartheta_{\text {, }}$ що використовується в методі подвійного клина:

а) для клина 2; б) для клина 1

Для підтвердження надійності роботи споруд з ґрунту, підсилених георешітками, були проведені багаточисельні натурні їх випробування при сейсмічних впливах. 16 червня 2009 відбулися випробування фрагмента конструкції армогрунтової підпірної стінки, виконаної за технологією Tensar, на сейсмічну стійкість при дії землетрусу, прогнозованого для регіону м. Сочі (8-9 балів за шкалою MSK-64) [3]. Об'єктом випробувань був фрагмент натурної конструкції армогрунтової підпірної стінки з розміром фасадної поверхні 3,5х2,6 м.

Облицювання фасаду стінки (рис. 6, а) виконана з 23 рядів вібропресованих бетонних блоків 400×150×220 мм з кутом нахилу облицювання $86^{\circ}$. Грунт засипки - пісок, армований одновісними георешітками Tensar. Георешітки, довжиною 3,0 м, були закріплені між облицювальними блоками за допомогою спеціальних конекторів, які забезпечували необхідну міцність з'єднання армогрунту з облицюванням.

В ході випробувань відтворювався багатокомпонентний рух сейсмоплатформи з параметрами, що відповідають умовам розташування об'єкта на поверхні ґрунту в сейсмонебезпечному регіоні м. Сочі.

При проведенні сейсмічних випробувань натурного фрагмента підпірної стінки Tensar вимірювалися переміщення блоків облицювання щодо реперної панелі, встановленої перед фасадною поверхнею облицювання, тиск ґрунту на стінки ґрунтового лотка і на облицювання, прискорення і переміщення верхнього ряду блоків облицювання, сейсмоплатформи і стінок ґрунтового лотка. Результати натурних випробувань армогрунтової підпірної стінки наведені на ри- 
сунку 6, б. Загальний вид на сейсмовибуховий стенд (сейсмоплатформу) та схема ії роботи наведено на рисунку 7.
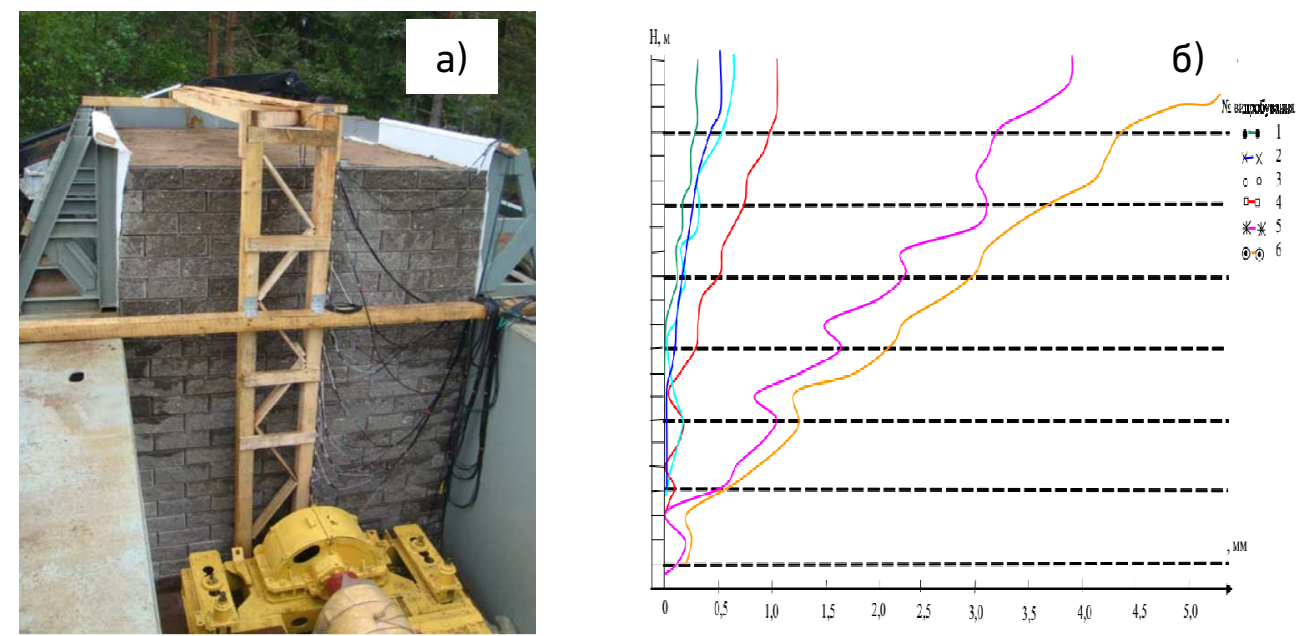

Рис. 6. Натурні випробування конструкції підпірної стінки, підсиленою георешітками:

а) загальний вид підпірної стінки; б) максимальні відносні переміщення блоків центрального поперечного перерізу підпірної стінки

Примітка 1. Пунктиром показані рівні встановлення георешіток в армованому грунті.

Примітка 2. Цифрами показано номери дослідів.

Залишкові зміщення точок вільної поверхні ґрунту в лотку фіксувалися після випробувань за допомогою координатного відліку i фотозйомки, а також вимірювалися і реєструвалися: прискорення у вертикальній і горизонтальній площинах з амплітудами до $50 \mathrm{~m} / \mathrm{c}^{2}$ $(5 \mathrm{~g})$ і з частотним діапазоном від 0 до 100 Гц; зміщення вертикальній і горизонтальній площинах з амплітудами до 0,25 м і з частотним діапазоном 0-10 Гц; відносні зміщення блоків облицювання з амплітудами до 0.06 м і з частотним діапазоном 0-10 Гц; тиск ґрунту з амплітудами до $10 \mathrm{kг} / \mathrm{cm}^{2}$ і з частотним діапазоном від 0 до 30 Гц. Відносна похибка результатів вимірювань при випробуваннях при прийнятих способах тарування і замірах не перевищує $10 \%$ з ймовірністю $\mathrm{p}=$ 0,99 . Максимальне значення горизонтального прискорення сейсмоплатформи склало 0,24 g, вертикальне прискорення - 0,27 g.

Максимальне значення горизонтального прискорення сейсмоплатформи складала 0,24 g, вертикального прискорення - 0,27 g. Повномасштабні стендові сейсмічні випробування фрагмента армогрунтової підпірної стінки Tensar повністю підтвердили її сейсмостій- 
кість при відтворенні на сейсмоплатформі СГД-75 сейсмічних навантажень, відповідним за амплітудним і частотним характеристикам впливу землетрусу, прогнозованого для регіону р. Сочі і заданого як розрахункове. При проведенні випробувань виявлено наявність значних (в 2-3 і більше разів) запасів сейсмостійкості конструкції по відношенню до розрахункового сейсмічного впливу.

a)

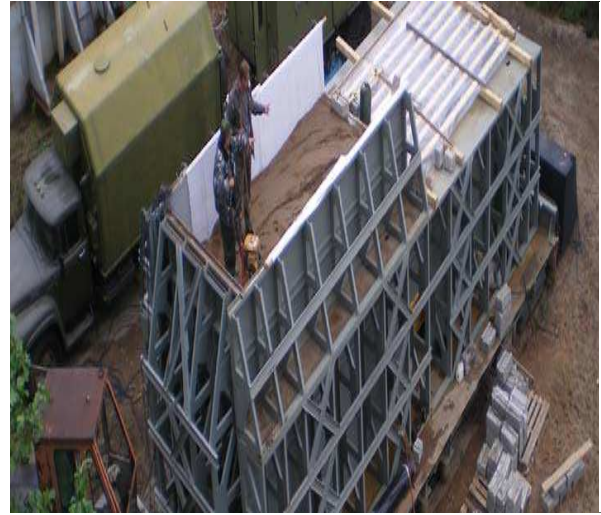

б)

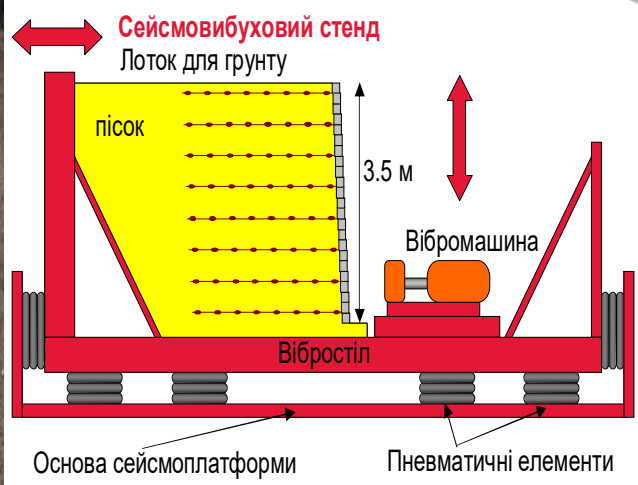

Рис. 7. Вид на сейсмовибуховий стенд (сейсмоплатформу) (а) та його схема (б)

На рисунку 8 наведені об'єкти в різних країних світу, побудовані за технологією Tensar (підпірні стінки, автомобільні дороги, підсилення схилів, основ для зведення шляхопроводів та інших споруд).

В 2018 році за проектом «ОдесаГіпродор» і ТОВ «УНІПРОМ» завершено будівництво об'єкта в Одеській області (сейсмічність району 9 балів за шкалою Ріхтера) на підходах до шляхопроводу над залізничною дорогою Рені-Налівна («Обхід м. Рені») (рис. 8, в, г). Для підсилення замуленої болотистої місцевості застосували геосотові матраци (Geocell) для створення надійної основи для насипу висотою 11 м. Така конструкція $\epsilon$ альтернативою стандартним методам будівництва на слабких ґрунтах. 12 лютого 2019 р. Президент України Петро Порошенко відкрив автомобільний обхід міста Рені.

Одновісна георешітка Tensar RE580 була використана як армування ґрунтової засипки при влаштуванні 2,5-кілометрової підпірної стіни висотою до 10 метрів вздовж прибережної державної дороги в Новій Зеландії (рис. 8, д, е). Цей «Проект життя», який зайняв 2 мільйони робочих годин, завершився перемогою в номінації «Приз глядацьких симпатій» (ICE) 2018 року в Лондоні. 


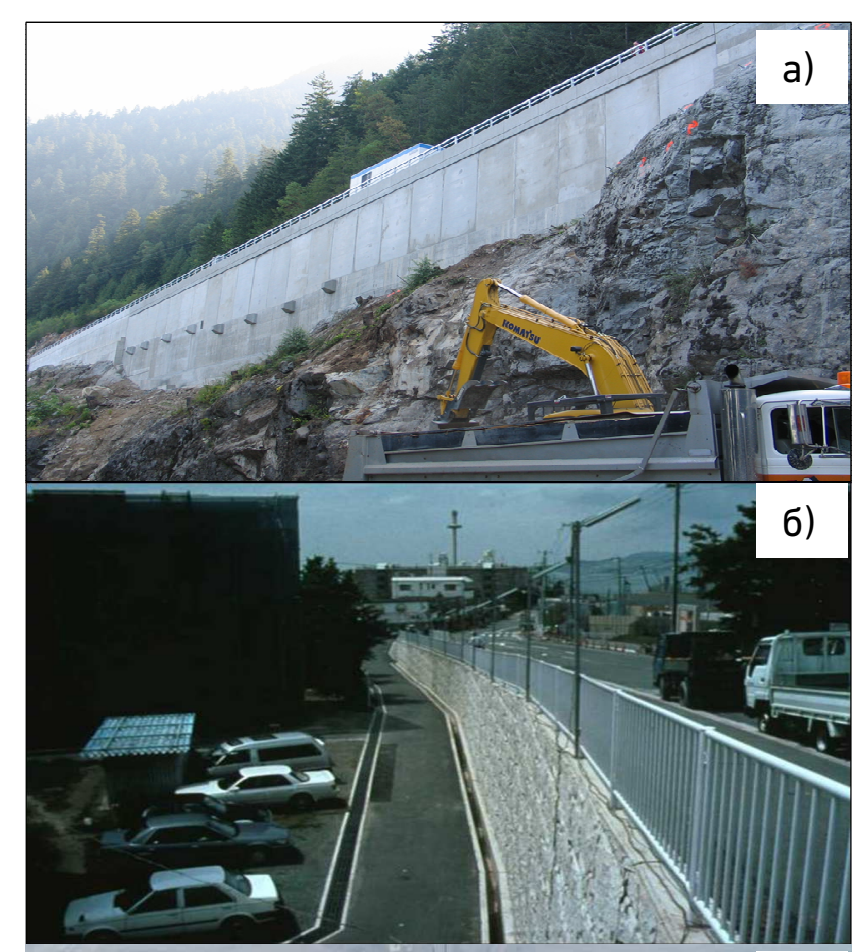

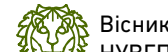

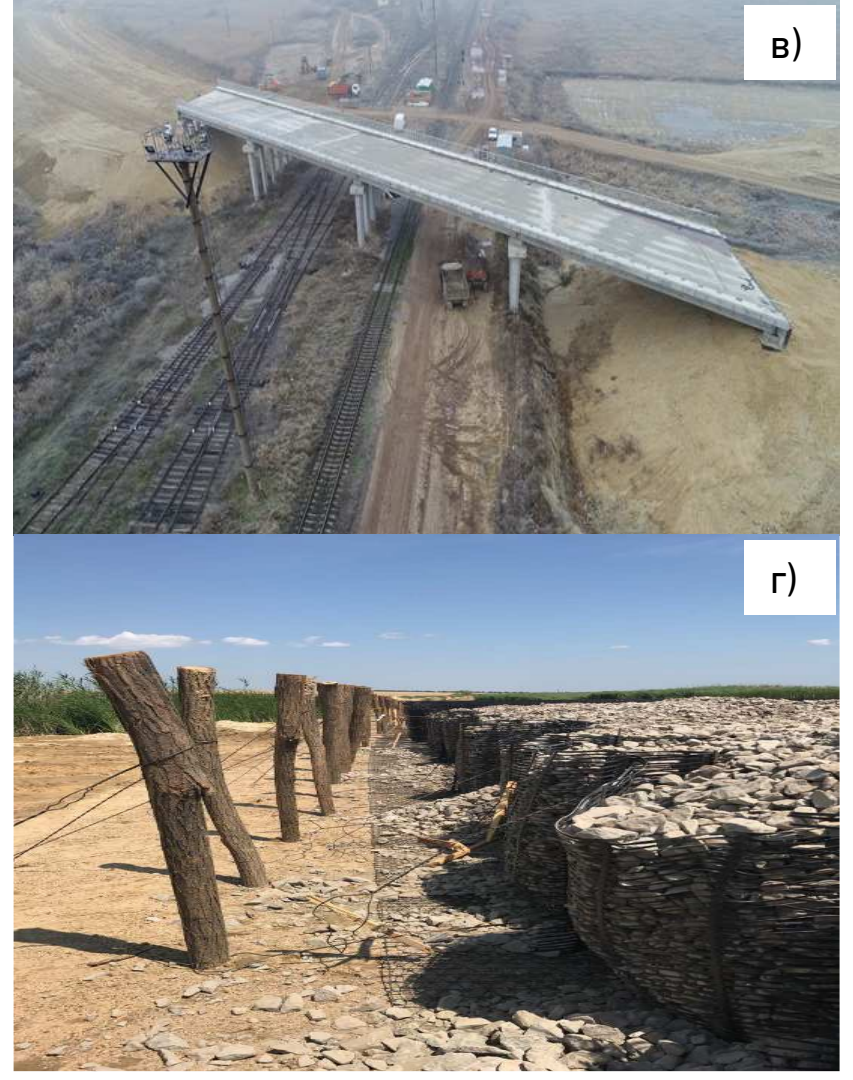




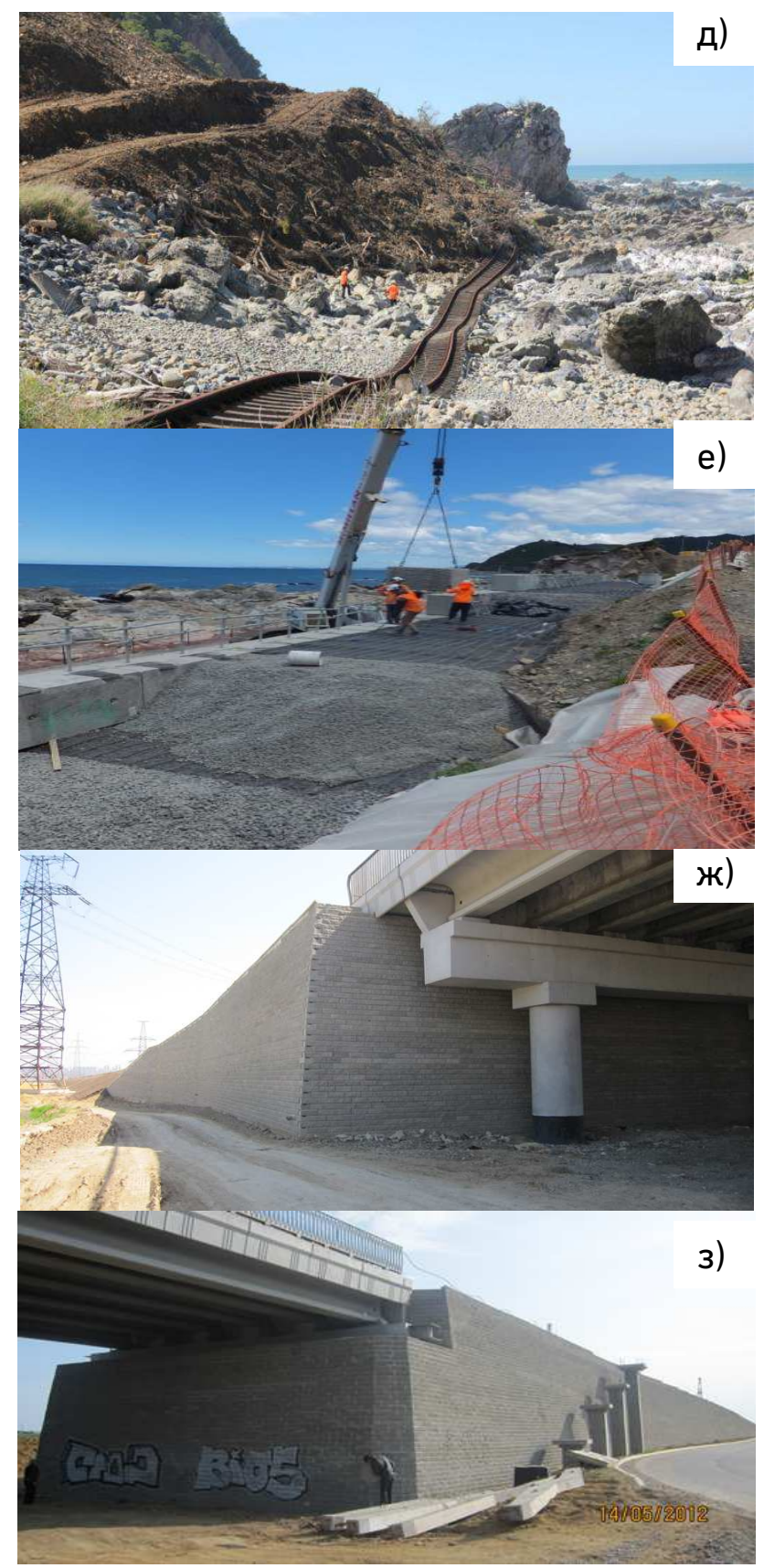

Рис. 8. Об'єкти, на яких застосовані технології Tensar:

а) 'Sea to Sky' Вистлер-Ванкувер (Канада), Зимова Олімпіада 2010 р.; б) Кобе (Япония), 1995 р.; в) вид на шляхопровід на залізничній дорозі РеніНалівна; г) будівництво геосотового матраца (Geocell) на залізничній дорозі Рені-Налівна; д) вид на дорогу уздовж узбережжя Кайкюра (Нова Зеландія) після землетрусу; е) будівництво дороги уздовж узбережжя Кайкюра (Нова Зеландія); ж) Куяльницький шляхопровід, 2009 р.; з) міст біля с. Нерубайське (автодорога Київ-Одеса) 
Підсилення ґрунту георешітками було застосовано в конструкції підпірної стіни, побудованої на підходах до шляхопроводу довжиною 500 м в районі села Нерубайське над Одеськими катакомбами (рис. 8, ж, 3). Армування ґрунту засипки жорсткими одновісними георешітками RE500 дозволило повністю зняти бічний тиск ґрунту на фронтальну стіну і опори шляхопроводу.

Натурні випробування ґрунтових споруд полігону для захоронення твердих відходів, з коефіцієнтом закладення укосу 1,3, армованих георешітками, проведено у Каліфорнії США з моделюванням землетрусу магнітудой 6,9 балів [5]. Полігон знаходиться у місті Монтерей-Парк (південна частина Каліфорнії) приблизно в 16 км на схід від центру Лос-Анджелеса в районі з високою сейсмічністю (7 балів за шкалою Ріхтера). Полігон використовувався як піщано-гравійний кар'єр, глибиною понад 30 м. За 40-річний період після припинення видобування піску і гравію полігон використовувався для розміщення муніципальних, комерційних, промислових твердих та рідких небезпечних відходів. Після закриття полігону в 1984 році, висота відходів становила від 21 до 100 м над рівнем землі.

У 1987 році був укріплений схил полігону на довжині 460 метрів, підсилений одновісними георешітками, як армуючими елементами, з використанням піщаного гравію, як матеріалу засипки. Нижня частина кріплення була встановлена на палях, які спиралися на відходи, тому з часом виникли деформації понад 600 мм. Для оцінювання внутрішньої стабільності схилу, підсиленого георешітками, на полігоні були проведені дослідження для оцінки його довготривалої міцності армованого ґрунту при статичних і сейсмічних навантаженнях. Необхідність проведення досліджень на полігоні була обумовлена наступними причинами: наявністю крутих укосів (закладання укосу 1:1,3), що примикають до 60-го хайвею; близькістю житлових будинків; сильним сейсмічним впливом (7 балів за шкалою Ріхтера). Було виконано три серії навантажень зразків: 1) швидке навантаження (2\% та $10 \%$ (від довготривалої міцності георешітки) за хвилину); 2) постійне навантаження (для оцінки повзучості при навантаженні 26,3 кH/м на розтяг, що відповідає 90 \% від довготривалої міцності георешітки); 3) швидке навантаження після повзучості, яке проводилося після стадії повзучості до руйнування георешітки при розтягу. При швидкому навантаженні (серія $1 \%$ і $10 \%$ за хвилину) через 100 годин випробувань на повзучість (серія 2), георешітка показала більшу жорсткість, ніж та, що спостерігалася при еквівалентному постійному навантаженні на розтяг (серія 3). При швидкому нава- 
нтаженні (серія 1\% і 2\% за хвилину) георешітка показала ще більшу жорсткість, ніж в серії 3.

При сейсмічному моделюванні роботи полігону сміття методом кінцевих елементів при землетрусі магнітудою 6,9 балів генерувалося горизонтальне прискорення 0,61 g на поверхні ґрунту. При цьому максимальне горизонтальне прискорення грунту сягало $1,0 \mathrm{~g}$ у верхній частині ґрунтової споруди за результатами розрахункового землетрусу (рис. 9).

Величина максимальних зусиль в георешітках при горизонтальному прискоренні ґрунту $1,0 \mathrm{~g}$ (для 9-го шару георешітки) становила приблизно 8,5\% від довготривалої міцності георешітки на розтяг $(26,3$ кH/м), що нижче $20 \%$ допустимих зусиль при комбінованих статичних і динамічних навантаженнях (рис. 9).

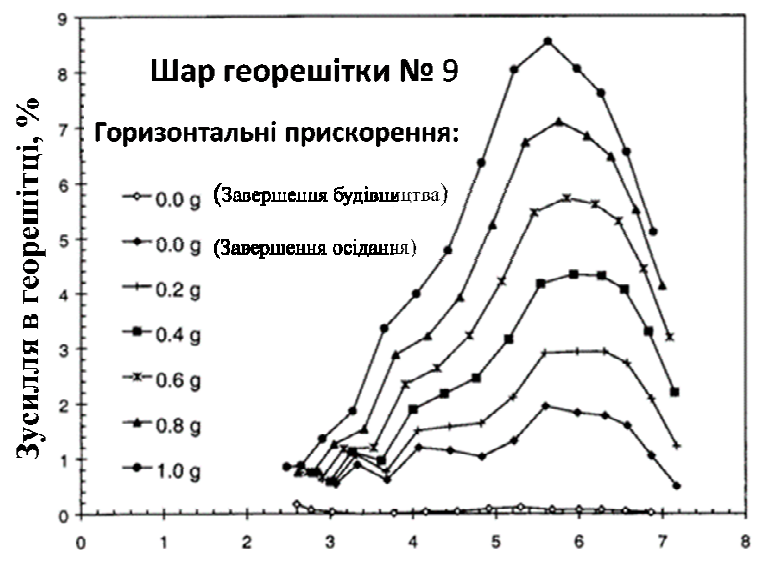

Відстань по горизонталі від підошви споруди, м

Рис. 9. Оціночні зусилля в георешітці, викликані сейсмічними діями

ВИСновКИ. 1. Аналіз роботи георешіток в різних конструкціях і грунтових спорудах і різних інженерно-геологічних умовах, включаючи експлуатацію в сейсмічних районах та багаточисельні натурні випробування ґрунтових споруд, підсилених георешітками, при сейсмічних діях 7-9 балів за шкалою MSK-64, свідчать про їх ефективність та надійність роботи в умовах довгострокової експлуатації.

2. Аналіз та узагальнення досвіду застосування споруд з ґрунтових матеріалів, армованих георешітками, в Японії, Новій Зеландії, Тайвані, Росії, Україні та інших країнах, свідчать про їх ефективність та надійність роботи, особливо, в умовах сейсмічних впливів 8, 9 балів. 
1. ДБН В 1.1-46:2017. Інженерний захист територій, будівель і споруд від зсувів та обвалів. Основні положення. [Чинні від 2017-25-04]. К. : Мінрегіон, 2017. 43 с. (Державні будівельні норми України). 2. ДСТУ-Н Б В 1.1-38:2016. Настанова щодо інженерного захисту територій, будівель і споруд від підтоплення та затоплення. [Чинні від 2017-04-01]. К. : УкрНДНЦ, 2017. 135 с. (Державний стандарт України). 3. ГБН В.2.3-37641918-544:2014. 3астосування геосинтетичних матеріалів у дорожніх конструкціях. Основні положення. [Чинні від 2015-01-01]. К. : Мінінфраструктури, 2014. 143 с. (Галузеві будівельні норми України). 4. Протокол стендовых сейсмических испытаний фрагмента конструкции армогрунтовой подпорной стенки, выполненной с использованием технологий Tensar. (Договор № 36/08 от 04 декабря 2008 г. между научно-проектной фирмой «Атом-Динамик» и 000 «Тенсар Интернэшнл»). 5. Джорж Зорнберг, Єдвард Кавазаніан Оцінка ефективності георешітки, що підсилює схил полігону твердих відходів, грунти і фундаменти. Японське Геотехнічне Суспільство. Т. 41, № 6, грудень 2001. С. 1-16.

\section{REFERENCES:}

1. DBN V 1.1-46:2017. Inzhenernyi zakhyst terytorii, budivel i sporud vid zsuviv ta obvaliv. Osnovni polozhennia. [Chynni vid 2017-25-04]. K. : Minrehion, 2017. 43 s. (Derzhavni budivelni normy Ukrainy). 2. DSTU-N B V 1.1-38:2016. Nastanova shchodo inzhenernoho zakhystu terytorii, budivel i sporud vid pidtoplennia ta zatoplennia. [Chynni vid 2017-04-01]. K. : UkrNDNTs, 2017. 135 s. (Derzhavnyi standart Ukrainy). 3. HBN V.2.3-37641918-544:2014. Zastosuvannia heosyntetychnykh materialiv u dorozhnikh konstruktsiiakh. Osnovni polozhennia. [Chynni vid 2015-01-01]. K. : Mininfrastruktury, 2014. 143 c. (Haluzevi budivelni normy Ukrainy). 4. Protokol stendovykh seismicheskikh ispytanii frahmenta konstruktsii armohruntovoi podpornoi stenki, vypolnennoi s ispolzovaniem tekhnolohii Tensar. (Dohovor № 36/08 ot 04 dekabria 2008 h. mezhdu nauchno-proektnoi firmoi «Atom-Dinamik» i 000 «Tensar Interneshn(»). 5. Dzhorzh Zornberh, Yedvard Kavazanian Otsinka efektyvnosti heoreshitky, shcho pidsyliuie skhyl polihonu tverdykh vidkhodiv, hrunty i fundamenty. Yaponske Heotekhnichne Suspilstvo. T. 41, № 6, hruden 2001. S. 1-16.

\footnotetext{
Hurtyna L. H., Chief Engineer (LLC "UNIPROM", Kyiv), Kharyn P. L., Head of Progekt Group (LLC "UNIPROM", Kyiv), Khlapuk M. M., Doctor of Engineering, Professor, Director Educational and Scientific Institute of Water Management and Environmental Engineering (National University of Water and Environmental Engineering, Rivne), Shuminskyi V. D., Candidate of Engineering (Ph.D.), Leading
} 
Researcher (State Enterprise «State Research Institute of Building Structures», Kyiv)

\section{EFFICIENCY OF THE STRUCTURES FROM SOIL MATERIALS REINFORCED WITH GEOGRIDS, TAKING INTO ACCOUNT SEISMIC EFFECTS}

Modern geosynthetics have great opportunities for solving many problems in the transport sectors, construction, hydraulic engineering construction, reconstruction and facilities operation. The main application areas for geosynthetics matirials are roads construction, drainage structures, reinforcement soil structures, protective structures, waterproofing structures and erosion control protection. There are about 380-400 different types of the geosynthetic materials in the world today and emergence of the new materials is so fast that it is mostly ahead all information about them. The wide application of the geosynthetic materials for biulding construction is caused by their high physical and mechanical properties such as durability, resistance to influence of climatic and hydrological factors, durability and mainly ecological safety. The geosynthetic materials have 40-120 years of durability, if they have not serious damage. The article considers the using of geosynthetic materials, which are include geotextiles, geogrids, geomembranes, geocomposites and which are used for various types of construction. Special attention is paid for geogrids, the peculiarities of their work and their use as reinforcing elements for soil retaining structures in various areas of the economy, the efficiency and durability of their work, including work in seismic regions. The main purpose of using geogrids is to increase the strength and reliability of the structure, its performance, especially in seismic conditions. The calculations of reinforced structures from the soil, which are performed in two stages: stage 1 includes the calculation of the total (external) stability of the structure, which determines the overall dimensions of the structure of reinforced soil and the length of geogrids. Stage 2 concerns based on local (internal) stability (the method of "double wedge"), in which the strength is checked and the vertical step geogrids connection strength of geogrid to the facings. When constructing structures in seismic areas, seismic actions are taken into account in stability calculations. The results of full-scale tests of structures made of ground materials reinforced with geogrids in seismic conditions and the positive experience of 
their operation in many countries in seismic regions, which can be used in making technical decisions to improve the efficiency of such structures and the choice of design solutions for their protection from seismic effects.

Keywords: geogrid uniaxial, biaxial and triaxial, geogrid reinforcement of structures made of ground materials, retaining walls, seismic effects, full-scale tests.

Гуртина Л. Г., главный инженер (ОАО «УНИПРОМ», г. Киев), Харин П. Л., заведующий проектной группой (ОАО «УНИПРОМ», г. Киев), Хлапук Н. Н., д.т.н., проф., директор учебно-научного института водного хозяйства и природообустройства (Национальный университет водного хозяйства и природопользования, г. Ровно), Шуминский В. Д., к.т.н., ведущий научный сотрудник (ГП «Государственный научноисследовательский институт строительных конструкций», г. Киев)

ЭФФЕКТИВНОСТЬ РАБОТЫ СООРУЖЕНИЙ ИЗ ГРУНТОВЫХ МАТЕРИАЛОВ, УСИЛЕННЫХ ГЕОРЕШЕТКАМИ, С УЧЕТОМ СЕЙСМИЧЕСКИХ ВОЗДЕЙСТВИЙ

В статье рассмотрено применение синтетических материалов, которые включают в себя геотекстили, геосетки, геомембраны, геокомпозиты и георешетки, используемые в различных сферах строительства. Особое внимание уделено георешеткам, особенностям их работы и использования их в качестве армирующих элементов в сооружениях из грунтовых материалов различного назначения, в различных областях народного хозяйства, обоснована эффективность и надежность их работы, включая работу в сейсмических регионах. Главная цель применения георешеток - повышение прочности и надежности конструкции, ее эксплуатационных показателей, особенно в условиях сейсмических воздействий. Представлены расчеты армированных сооружений из грунта, которые выполняются в два этапа: этап 1 включает в себя расчет общей (внешней) устойчивости сооружения, при котором определяются габаритные размеры сооружения из армированного грунта и длины георешеток; етап 2 касается расчета на местную (внутреннюю) устойчивость (метод «двойного клина»), при котором проверяется прочность и вертикальный шаг георешеток, прочность со- 
единения георешеток с облицовкой. При устройстве сооружений в сейсмических районах в расчетах устойчивости учитываются сейсмические действия. Сделан анализ работы георешеток в различных сооружениях, особенно при усилении ними сооружений из грунтовых материалов, а также при многочисленных натурных испытаниях в различных условиях при сейсмических воздействиях. Определены основные сферы применения геосинтетиков. Представлены результаты натурных испытаний сооружений из грунтовых материалов, усиленных георешетками, в условиях сейсмических воздействий и положительный опыт их эксплуатации во многих странах в сейсмических регионах, которые могут быть использованы при принятии технических решений по повышению эффективности работы таких сооружений и по выбору конструктивных решений их защиты от сейсмических воздействий. Ключевые слова: георешетки одноосные, двухосные и трехосные, армирование георешетками сооружений из грунтовых материалов, подпорные стенки, сейсмические воздействия, натурные испытания. 